\title{
NEFORMALNO IZOBRAŽEVANJE V DRUŽINAH NA JESENICAH
}

\section{POVZETEK}

Svet Evropske unije in parlament v Bruslju sta novembra 2006 sprejela Resolucijo o vseživljenjskem izobraževanju do leta 2013. Na Resolucijo, ki poudarja pomen vseživljenjskega izobraževanja v družbi naglih sprememb, bomo morali biti pozorni tudi v naši družbi pri uvajanju vseživljenjskega izobraževanja na individualni in institucionalni ravni ter na vseh področjih javnega in zasebnega življenja. Zaradi hitrega razvoja in velikih sprememb se moramo učiti mnogo hitreje, po načrtovani poti in naravnano k jasnim ciljem. Izobraževalni proces se seli iz formalnih institucij v človekov intimni svet in se odziva na najosebnejše vzgibe, prav zaradi tega pa na pomenu dobiva neformalno izobraževanje, ki ubira bolj spontane poti, vraščene $v$ zivljenje, potrebe in druge spremembe.

Ključne besede: neformalno izobraževanje, družina, družinsko okolje, vseživljenjsko izobraževanje

članku želimo pokazati družinsko okolje kot pomemben dejavnik, ki otroke spremlja in usmerja na njihovi poti učenja in izobraževanja ter vpliva na njihovo učno uspešnost. Osnove znanja in izkušenj dobijo otroci v primarni družini in znanje dopolnjujejo v interakciji s šolskim okoljem. Poleg ožjega okolja (družine), v kateri otrok odrašča, pa vpliva na razvoj otroka tudi širše okolje s svojo kulturno, socialno in materialno razvitostjo.

Spomladi 2006 smo s pomočjo anketnega vprašalnika izvedli raziskavo, kako družine koristijo možnosti neformalnega izobraževanja, ki jih ponuja širše in ožje okolje. V empirično obdelavo je bilo zajetih 69 družin učencev osmega razreda osnovne šole na Jesenicah.

$\mathrm{V}$ raziskavi smo raziskali lokalna središča neformalnega izobraževanja na Jesenicah in ugotovili, da je možnosti za neformalno izobraževanje kar nekaj, vendar jih anketirane družine le $v$ manjši meri izkoriščajo. Ugotavljamo, da družine pri osebnem iskanju novega znanja še ne znajo v zadostni meri iskati virov znanja $v$ svojem neposrednem okolju. Iskanje različnih poti pri pridobivanju znanja pa je $\mathrm{v}$ današnjem času pomembno, saj vsega znanja eno samo učno okolje ne more več dati. Potrebe po izobraževanju so velike, zato mora biti človek izpostavljen več različnim učnim okoljem. Brez raznolikosti v učenju ljudi ni vseživljenjskega izobraževanja. Ljudje se namreč med seboj razlikujemo po tem, čemu dajemo prednost, na kaj smo pozornejši, kaj imamo raje in kaj nas odbija. Osebno iskanje novega znanja pa je povezano tudi s socialnimi razmerami in kulturnimi navadami posameznika in kraja. 


\section{KAKO SE NEFORMALNO IZOBRAŽUJEJO DRUŽINE NA JESENICAH?}

Svet Evropske unije in parlament $v$ Bruslju sta novembra 2006 sprejela Resolucijo o vseživljenjskem izobraževanju do leta 2013. Resolucija potrjuje, da je Evropa nedvomno v času hitrih sprememb, ki jih doživljamo na različnih področjih (družbene, tehnične,

Družinsko okolje usmerja otroke na poti njihovega nadaljnjega učenja in izobraževanja.

kulturne, gospodarske spremembe). Te spremembe lahko povsem spremenijo način našega življenja, dela, vrednot, pojmovanj. Da bi se posameznik uspešno spopadel $s$ spreminjajočim se svetom, se mora nenehno izgrajevati, izpopolnjevati. Potrebe po izobraževanju spremljajo človeka skozi vse življenje. Prav zaradi množičnosti pa vseh potreb ne moremo zadovoljiti zgolj po formalni poti. Pomembne postajajo tudi neformalne poti pridobivanja znanja, zlasti tiste, ki so osebno obarvane in povezane s socialnimi in kulturnimi navadami posameznika in kraja. Novim potrebam ljudi se mora nenehno prilagoditi tudi izobraževanje: politika, ponudba, izpeljava ... Na Reso-

\section{Učenje na podlagi zgolj osebnih izkušenj ne zadošč več.}

lucijo o vseživljenjskem izobraževanju bomo morali biti pozorni tudi v naši družbi pri uvajanju vseživljenjskega izobraževanja na individualni in institucionalni ravni ter na vseh področjih javnega in zasebnega življenja. Znotraj vseživljenjskega izobraževanja je potrebno še posebej poudariti pomen neformalnega izobraževanja, saj uresničevanje vseživljenjskega izobraževanja poteka zlasti po neformalni poti.

\section{VSEŽIVLJENJSKO IZOBRAZ̆EVANJE, VSEŽIVLJENJSKO UČENJE}

Paul Lengrand je na svetovni konferenci $v$ Montrealu predstavil koncept permanentnega izobraževanja. Izraz permanentno izobraževanje je bil v strokovni literaturi razširjen $v$ šestdesetih in sedemdesetih letih, $v$ angleški strokovni literaturi pa so namesto tega izraza uporabljali izraz vseživljenjsko izobraževanje. Oba izraza sta bila v strokovni literaturi prisotna $v$ osemdesetih letih in $\mathrm{v}$ začetku devetdesetih let, ko pa so se potrebe po znanju, novih sposobnostih in osebnostnih lastnostih izrazito povečale, se je zlasti $v$ politiki vedno pogosteje uporabljal izraz vseživljenjsko učenje. Toda izraz vseživljenjsko učenje je preveč ohlapen in neobvezujoč, saj se ljudje učijo vse življenje, odkar obstaja človeštvo. V času hitrih sprememb in naglega razvoja ni mogoče, da bi se zanašali na to, da nas bo učilo samo življenje $\mathrm{z}$ različnimi pripetljaji in vtisi (Krajnc, 1997, str. 3). Vzgoja in izobraževanje nista dokončan proces, $s$ pojavom permanentnega izobraževanja se izobraževanje prepleta $z$ vsemi drugimi aktivnostmi in postane življenjski način (Krajnc, 1996, str. 8). Tudi Paul Lengrand je poudaril, da učenje na podlagi osebnih izkušenj v svetu hitrih sprememb ne zadošča več. Ljudje si morajo znanje pridobivati skozi vse življenje in pri tem mora biti pridobivanje novega znanja, stališč, vrednot in sposobnosti načrtno, ciljno naravnano in strukturirano (Lengrand, 1970, str. 49). Izobraževanje je posebna, višja oblika učenja, ki je bolj zgoščena in zato izobraževanja ne moremo zamenjati $\mathrm{z}$ učenjem (Krajnc, 1998, str. 34).

Koncept vseživljenjskega izobraževanja je razvila informacijska družba. $V$ tej družbi ljudje ne morejo več živeti samo od svojega dela, pomembno postane njihovo znanje, ose- 
bnostne lastnosti in sposobnosti. Ljudje se ne morejo naučiti stvari vnaprej, enkrat za vselej, ampak si morajo znanja pridobivati sproti. Šolski sistem tako postane samo eden od nosilcev vzgoje, formalno in neformalno izobraževanje se pomešata, prepletata in se nadaljujeta $v$ osebnostnem razvoju posameznika (Toffler, 1992).

Uresničevanje vseživljenjskega izobraževanja poteka zlasti po neformalni poti in ubira bolj spontane poti, vraščene v življenje, potrebe in druge spremembe (Toffler, 1992).

\section{NEFORMALNO IZOBRAŽEVANJE}

Neformalno izobraževanje odraslih je tisto, $\mathrm{ki}$ se najhitreje odziva na zahteve in značilnosti znanstvenega, tehnološkega, gospodarskega, socialnega, kulturnega in na splošno družbenega razvoja. Globalne razvojne koncepcije in strategije, kot so družba učenja, vseživljenjskost ali permanentnost izobraževanja, globalno učenje ipd,, ter spoznanja o novih možnostih učenja, kot so organizirano samostojno učenje, učni projekti odraslih, multimedijsko izobraževanje, učenje ob računalniku, izobraževanje na daljavo, akcijsko učenje itn., gotovo vplivajo tako na izobraževanje mladine kot tudi na izobraževanje odraslih in tako na formal- no kot tudi na neformalno izobraževanje. Med vsemi navedenimi področji in vrstami izobraževanja se ta spoznanja in spremembe $v$ izobraževanju in učenju najbolj zrcalijo $v$ razvoju neformalnega izobraževanja odraslih. Neformalno izobraževanje odraslih je tisto področje, ki ima izjemno veliko motivacijsko in socializacijsko moč, je neposredno povezano $z$ vsemi našimi dejavnostmi, išče nove poti tam, kjer odpoveduje formalno izobraževanje, se povezuje $z$ izkušnjo in se $z$ njo potrjuje (Jelenc, 1992).

Neformalno izobraževanje odraslih je področje, ki ni enotno in enopomensko opredeljeno, kljub temu pa lahko mnoge in zelo različne opredelitve o neformalnem izobraževanju strnemo v dve temeljni opredelitvi in ga tako ločimo od formalnega izobraževanja.

Prva, starejša opredelitev izhaja iz tega, kako poteka izobraževanje; za neformalno izobraževanje poudarja, da sta v primerjavi $s$ formalnim izobraževanjem njegov potek in izvedba manj strogo določena in se zato lahko gibljivo prilagaja različnim ciljem, potrebam in možnostim.

Druga, novejša opredelitev opredeli kot neformalno izobraževanje vse tisto izobraževanje, ki se ga lahko udeleženci neovirano udeležijo (brez uradnih vpisnih pogojev) in ni name-

Terminologija izobraževanja odraslih neformalno izobraževanje odraslih opredeli kot strukturirano, sosledično organizirano izobraževanje za odrasle, ki ni namenjeno pridobivanju formalnega izkaza, kot so spričevalo, diploma, javno priznana stopnja izobrazbe ali usposobljenost, temveč je namenjeno zadovoljevanju nekaterih drugih, navadno neposrednih interesov in potreb odraslega. To je izobraževanje odraslih, pri katerem je učenje sicer namerno, učni proces pa ni strukturiran v obliki razredov ali pod vodstvom učitelja, ki naj bi bil odgovoren za izobraževanje učencev, niti ni potrebno, da bi se proces organiziral sosledično (Jelenc, 1991, str. 56).

Sami razumemo neformalno izobraževanje kot neko tematsko izobraževanje, zunaj profesionalnih ustanov, pri katerem se viri, čas in kraj nenehno spreminjajo. Učinkovitost tega izobraževanja je velika, ker poteka spontano in je prilagojeno posamezniku - izhaja iz njegovih življenjskih razmer. Neformalno izobraževanje vidimo kot pomembno možnost za srečevanje in združevanje ljudi. 
njeno pridobitvi formalnega izkaza o javno priznani izobrazbi ali znanju (Jelenc, 1991, str. 24).

\section{UČNA OKOLJA}

Tradicionalno smo poznali samo šolo kot učno okolje, danes pa govorimo o učnih okoljih v množini (Husen, 1974). Potrebe po izobraževanju so velike in jih zaradi

Množične potrebe po izobraževanju

ni vě̆ moč zadovoljiti zgoljs formalnim izobraževanjem.

množičnosti ni več mogoče zadovoljiti samo $s$ formalnim izobraževanjem. Človek mora biti izpostavljen več različnim učnim okoljem, vsaj vsega znanja eno samo učno okolje ne more več dati. Ljudje se izobražujemo v zelo različnih situacijah vsakdanjega življenja in smo tako izpostavljeni več različnim učnim okoljem. Brez raznolikosti $v$ učenju ljudi ne bi bilo vseživljenjskega izobraževanja. V današnjem času se ne smemo zanašati samo na organizirane formalne programe, kot so seminarji, tečaji, predavanja, temveč moramo izobraževalne možnosti ali učna okolja namerno iskati, izbirati in med seboj povezovati.

A. Tough je na podlagi svojih študij ugotovil, da se odrasli le do 20 odstotkov izobražujejo

Odrasli le 20

odstotkov novega

znanja pridobijo

po formalni

poti, drugo po

neformalni. po formalni poti, vse ostalo pa poteka po neformalni poti $v$ različnih učnih okoljih (Tough, 1971, str. 71).

Učno okolje lahko postane vsaka življenjska situacija, nuditi mora le spoznavne možnosti in biti zavestno povezana $\mathrm{z}$ učnim ciljem. Oseba mora imeti jasen cilj, kaj se hoče naučiti, opaziti, začutiti, sprejeti, si zapomniti (Krajnc, 2002, str. 3-5). Učno okolje so lahko izleti v naravo, potovanja, nakupovanja, obiski galerije, muzeja, pogovor s strokovnjakom, življenje s partnerjem, de- lovno okolje, družinsko okolje ... Učna okolja so zelo osebno obarvana. Kombinacija učnih okolij in možnosti je pri vsaki osebi drugačna, pa čeprav živi več ljudi v navidezno enakem okolju. Ljudje se namreč med seboj razlikujemo po tem, čemu dajemo prednost, na kaj smo pozornejši, kaj imamo raje in kaj nas odbija.

Osebno iskanje novega znanja je povezano tudi s socialnimi razmerami in kulturnimi navadami posameznika in kraja. Pri osebnem iskanju novega znanja so uspešni zlasti tisti, ki uporabijo za pridobivanje znanja vire v svojem neposrednem okolju (pogovarjajo se s partnerjem, telefonirajo prijateljem, se pogovarjajo s sosedi, sodelujejo z ljudmi, ki so jim blizu in jim zaupajo, $v$ domačem kraju poiščejo in si ogledajo to, kar bi se radi naučili, sposodijo si priročnik o tem, kar bi se radi naučili). Tako se v nekem kraju pojavijo določeni vzorci, strategije izobraževanja. Ti vzorci, strategije se začnejo širiti, ponavljati in ljudje jih posnemajo (Krajnc, 2000, str48-51). Ce v nekem kraju postane na primer branje časopisov navada in so mediji zelo popularni, ljudje začnejo tudi pri svojem osebnem izobraževanju ubirati te poti, še zlasti ko ugotovijo, da so se osebe okrog njih iz tega nekaj naučile.

\section{NEFORMALNO IZOBRAŽEVANJE $\checkmark$ DRUŽINI VPLIVA NA USPEŠNOST ŠOLANIA}

Družina je okolje, kjer začne otrok živeti in se razvijati. To je okolje, v katerem se začne oblikovati osebnost novega človeka, tu človek pridobi prve zaznave, prva doživetja, prva spoznanja in prve vrednote. Družinska vzgoja je osnova, $v$ kateri se razraščajo otrokova čustva, njihov odnos do stvarnosti, do pojavov, odnos do staršev, do drugih ljudi in do samega sebe. 
V družini otrok dobi prve vzore, spodbude, temelje za vseživljenjsko izobraževanje. Starši otrokom posredujejo svojo kulturo, svoj odnos do izobraževanja in vplivajo nanje, da jih posnemajo. Pri tem ne gre za kulturo v ožjem smislu, za umetnost, temveč za kulturne odnose med družinskimi člani, za kulturno izkoriščanje prostega časa, za kulturo prehranjevanja, kulturo jezikovnega izražanja ... skratka, gre za kulturnost življenja (Bergant, 1971, str. 83).

Šved Torsten Husen (Husen, 1974) je objavil knjigo o družbi, ki se uči od rojstva do smrti, na vsakem koraku. Smiselno in utemeljeno je govoriti tudi o učeči se družini, saj gre $\mathrm{v}$ skupnem bivanju in razmišljanju članov družine tudi za učenje. Družina namreč ustvarja svojo družinsko kulturo, svojo učno klimo in lahko predstavlja pomembno učno okolje vsem članom. Družinsko življenje se lahko odvija v kontekstu spodbudnega učnega okolja ali pa okolja, ki ne sledi spremembam družbe in kjer ělani družine ostajajo pasivni subjekti svojega okolja. Tudi v družini bi si morali družinski člani načrtno prizadevati in se izobraževati za višjo kakovost življenja $v$ družini, za večjo prožnost ob zunanjih spremembah in za boljše odnose v družini.

Kadar govorimo o izobraževanju v družini, marsikdo najprej pomisli na domače naloge, na pomoč otrokom pri šolskem učenju, morda tudi na učenje staršev, ki se npr. izobražujejo ob delu. Toda toje le majhen del izobraževanja, ki poteka $v$ družini.

$V$ družini se medsebojno izobražujemo tako, da skupaj doživljamo dogodke. Za to pa potrebujemo skupen čas. Družinski prosti čas je pomemben za vso družino in ni vseeno, kako si ga organiziramo (Ličen, 1998, str. 3435). Starši in drugi družinski člani bi morali znati izbirati prostočasne dejavnosti kritično ter odgovorno do sebe in do otrok. Zgled ima namreč veliko moč. Težko se odvadimo pasivnega preživljanja prostega časa (npr. pred televizijskim sprejemnikom), zato je ugodneje, da se posameznik že $v$ otroštvu nauči takih dejavnosti, ki so ustvarjalne, rednosti in discipliniranosti v delovanju, učenja obvladovanja sebe in prostega časa.
Okolje s svojo kulturno, socialno in materialno razvitostjo vpliva na otroke. Najprej je to ožje socialno okolje $v$ družini, kjer je najpomembnejši vpliv staršev.

Šolski uspeh je čedalje bolj odvisen od izobrazbe staršev. Povezan pa je tudi $s$ kulturo in $\mathrm{z}$ razvitostjo okolja. Neformalno učenje že pri otoku dopolnjuje šolanje, brez podpore iz okolja je učenec neuspešen.

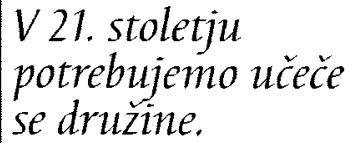

Bergant (1962) meni, da otroke v neugodnem okolju ovirajo pri uspešnosti $v$ šoli mnogi dejavniki. Otrok, ki živi v manj ugodnem okolju, ima manj izkušenj o svetu in življenju. Starši imajo manj časa in priložnosti, da bi se lahko $\mathrm{z}$ otrokom ukvarjali, pogosto pa za to tudi nimajo ustreznega znanja. Otrok, ki živi v takšni družini, ima na voljo manj knjig, leksikonov, časopisov, revij. Razen tega otrok lahko nima možnosti, da bi se izobraževal zunaj doma, da bi šel v kino, muzej, si ogledal razstave in obiskoval kulturne prireditve, ker teh možnosti $v$ njegovem okolju ni, ali pa jih je zelo malo. $V$ manj ugodnem

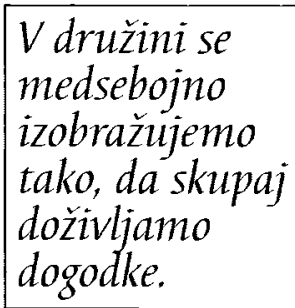
okolju je na splošno tudi manj interakcij med odraslimi in otroki. $\mathrm{V}$ družinah je manj komunikacij, zato imajo otroci tudi manj izkušenj in se jezikovno slabše izražajo. Jezikovni primanjkljaji pa ovirajo otrokovo uspešnost v šoli. Ovira pri otrokovi uspešnosti v šoli je lahko tudi nizko vrednotenje pomena izobraževanja v družini. Starši, ki ne vrednotijo izobraževanja in izobraževanju ne namenijo dovolj pozornosti, prenašajo na otroke

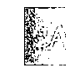




\begin{abstract}
V zadnjem času se vedno bolj poudarja tudi pomen družinske pismenosti, kjer gre prav tako za učenje vseh družinskih članov. Še več, z izboljšanjem ravni pismenosti staršev naj bi se izboljšala tudi raven pismenosti njihovih otrok ter s tem tudi njihova šolska uspešnost in njihova možnost za nadaljnje izobraževanje. Nekoč se je pismenost opredeljevala kot spretnost branja in pisanja, medtem ko jo danes opredeljujejo razne temeljne spretnosti, npr. bralne, pisne, računske, računalniške ... in temeljno znanje, npr. za iskanje in dostop do informacij (Knaflič, 2002).
\end{abstract}

vse prej kot interes za izobraževanje in s tem nižajo nivo otrokovih izobraževalnih prizadevanj (Bergant, 1962).

Poulson (1997) pojasnjuje, da je v primerih, ko imajo starši težave pri branju, pisanju in drugih temeljnih spretnostih, verjetneje, da se bodo $s$ podobnimi težavami soočili tudi njihovi otroci in da jim starši ne bodo mogli pomagati. Vpliv pismenosti staršev na raven pismenosti otrok kaže, da se določena raven pismenosti medgeneracijsko ohranja znotraj družine in da šola $v$ povprečju v majhni meri nadoknadi pomanjkanja na področju pismenosti, ki izvirajo iz družine. Pri tem je mišljeno predvsem, da so starši otrokovi prvi učitelji in s svojim ravnanjem prenašajo na otroke jezik, miselnost, vrednote, navade, kulturo ..., ki vladajo v družini (Knaflič, 1999).

\section{SREDIŠČA NEFORMALNEGA IZOBRAŽEVANJA NA JESENICAH}

Nastanek mesta Jesenice je povezan z razvojern fužinarstva ob reki Savi. Prav fužine pomenijo začetek Jesenic, saj je iz njih in okoli njih nastala sedanja železarna, ki daje Jesenicam pečat industrijskega mesta (http://www. jesenice.si/).

\section{Gornjesavski muzej Jesenice}

Muzejska dejavnost na Jesenicah je stara dobrih petdeset let. Tako kot večji del zgodovine Jesenic in Gorenjske, je tudi Gornjesavski muzej tesno povezan z železarstvom. Deluje kot samostojna strokovna institucija, od leta 1992. Osnovna naloga muzeja je varovanje kulturne dediščine na področju občin Jesenice in Kranjska Gora. Gornjesavski muzej Jesenice upravlja $z$ dvema graščinama: Ruardovo in Kosovo graščino (http://www.gornjesavskimuzej.si/).

\section{Ruardova graščina}

Ruardova graščina stoji v nekdanjem fužinskem naselju na Stari Savi na Jesenicah, ki je zaščiteno kot kulturni in tehniški spomenik. $V$ graščini je sedež Gornjesavskega muzeja Jesenice in stalna razstava o zgodovini rudarstva in železarstva na Gorenjskem. Od leta 1993 pa je na ogled tudi zbirka okamnelih rastlin in živali z zahodnih Karavank (http://www.gornjesavskimuzej.si/).

\section{Kosova graščina}

Kosova graščina sodi v sklop štirih fužinskih gradov, ki so jih $v 16$. in $v$ prvi polovici 17. stoletja zgradili lastniki železarskih obratov. Konec 19. stoletja je graščino skupaj z njenim gospodarskim poslopjem in velikim vrtom odkupila jeseniška srenja. Stavbo je kar 30 let uporabljala za ljudsko šolo, Jeseničani so ji pravili »stara šola«. Med okupacijo so jo Nemci preuredili v prehodne zapore. Danes so v njej občasnim razstavam namenjeni prostori (menjajo se različne likovne in muzejske razstave), stalni zbirki novejše zgodovine (stalne razstave o okupatorjevem terorju $\mathrm{v}$ letih 1941 do 1945, razstave o zgodovini delavskega gibanja v 19 . in 20 . stoletju ter o NOB na Jesenicah), v drugem nadstropju pa sta poročna dvorana in protokolarni občinski prostor, ki pogosto gosti kulturne prireditve (http://www.gornjesavskimuzej.si/). 


\section{Razstavni salon Dolik}

Razstavni salon Dolik je stalni prostor, namenjen razstavam različnih umetniških del. Tu so razne slikarske, kiparske, fotografske, prodajne razstave ... Ljudje se tu družijo, izmenjujejo informacije, spoznanja, nova znanja, se osebno uveljavljajo, ustvarjajo in neformalno izobražujejo (http://www.jesenicetourism.net/).

\section{Gledališče Toneta Čufarja}

Gledališče je bilo ustanovljeno leta 1945 kot Slovensko ljudsko gledališče Jesenice in od takrat deluje neprekinjeno pod različnimi imeni. Vsako leto premierno uprizorijo tri predstave za odrasle, eno predstavo študentske skupine in štiri predstave za otroke. $V$ gledališču organizirajo tudi veliko gostovanj drugih poklicnih in nepoklicnih gledališč, matineje za otroke, gledališke krožke in gledališko šolo. Organizirajo tudi glasbeni abonma. Od leta 2001 javni zavod opravlja tudi dejavnost kina v Kinu Železar (http:// www.gledalisce-tc.si/).

\section{Kino}

Dejavnost kina ima sicer na Jesenicah že bogato tradicijo, od leta 2001 pa s kinodvorano upravlja Gledališče Toneta Čufarja. Za filmski program je poskrbljeno od septembra do julija. Filme predvajajo ob petkih, sobotah in nedeljah oziroma po naročilu za šole ali druge naročnike (društva, klube ...). V juliju in avgustu zaradi manjšega interesa filmskih predstav ni. V času sezone pa organizirajo tudi filmsko gledališče. Dvorana Kina Železar, ki ponuja kar 414 sedežev, je primerna tudi za organizacijo drugih prireditev in najem (http://www.gledalisce-tc.si/).

\section{Občinska knjižnica Jesenice}

Knjižnica opravlja dejavnost splošne javne knjižnice za tri občine: Jesenice, Kranjsko Goro in Žirovnico. Razpolaga $\mathrm{z}$ več kot 110.000 izvodi knjig, 2.300 enotami neknjižnega gradiva (predvsem zgoščenke in zemljevidi) in letno $\mathrm{z}$ okrog 200 naslovi različne domače in tuje periodike. V knjižnici potekajo tudi različne dodatne dejavnosti za otroke: ure pravljic, igralne urice, angleške in nemške urice, knjižni kvizi, pogovori o knjigah ter različne delavnice. Knjižnica ima že enajst let računalniško podprto izposojo, od leta 1996 pa dostop do interneta in vzajemnega kataloga slovenskih knjižnic (http:// www.knjiznica-jesenice.org/novice.php).

\section{Društva}

Organizirano kulturno gibanje na Jesenicah in v okolici se je v primerjavi z drugimi območji pričelo precej pozno, kar je bilo v veliki meri povezano s splošno revščino, ki je vladala konec 19. stoletja na Gorenjskem. Jesenice so dobile šele leta 1885 prvo slovensko bralno in pevsko društvo, katerega osnovni namen je bil dramiti in krepiti slovensko narodno zavest. Ljubiteljska kultura se je v vsej svoji zgodovini srečevala s številnimi težavami, ki so bile posledica političnih, družbenih in ckonomskih sprememb. Kljub temu pa se je širila in razvijala. Rezultat tega so danes številna društva, katerih dejavnosti segajo na področja glasbe, plesa, folklore, umetniškega ustvarjanja, športa, izobraževanja in še na mnoga druga (http://www.jesenice-tourism. net/).

\section{Šport in rekreacija}

Jesenice nudijo številne možnosti za sprostitev, rekreacijo in aktivno preživljanje prostega časa. V Športnem parku Podmežakla je osrednji objekt športna dvorana z drsališčem, ki lahko sprejme 5000 gledalcev. Drsališče je za rekreacijo odprto med septembrom in aprilom. Vsako sezono pa je organiziranih tudi preko 160 hokejskih tekem in več turnirjev v kegljanju na ledu. Ena izmed zelo priznanih in odmevnih prireditev je vsakoletno mednarodno tekmovanje $v$ umetnostnem drsanju Triglav Trophy. Dvorana vsebuje tudi trim kabinet, fitnes in dvorano za namizni tenis. $\mathrm{V}$ poletnih mesecih je primerna tudi za orga- 
nizacijo zabavnih prireditev. V sklopu športnega parka so tudi tri pokrita in štiri dvoranska balinišča, zunanja igrišča za košarko, nogomet in tenis. $V$ poletnih mesecih pa je odprto tudi letno kopališče.

Naravoslovna in rudarska učna pot $v$ Javorniškem Rovtu nad Jesenicami pa je namenjena vsem, ki želijo odkrivati zakonitosti narave in ostanke preteklosti. Označena s tablami in smerokazi predstavlja naravni in zgodovinski »laboratorij« (http://www.jesenice-tourism.net/).

\section{MEDIJI IN ŠIRŠE MOŽNOSTI ZA NEFORMALNO IZOBRAŽEVANIE NA JESENICAH}

\section{Časopis}

Gorenjski glas je neprekinjeno prisoten že od leta 1977. Izhaja ob torkih in petkih, letno izide sto številk. V zadnjih letih so se namnožile priloge, ki predstavljajo že tretjino obsega časopisa. Z lokalnimi prilogami želijo pokriti vso Gorenjsko in tako ustvariti mrežo lokalnega tiska (http://www.gorenjskiglas. sil).

Jeseniške občinske novice (JON) so priloga, ki jo Gorenjski glas pripravlja s sodelovanjem Občine Jesenice. JON prihaja $v$ jeseniške domove vsak zadnji petek v mesecu, razen avgusta. Prilogo brezplačno dobijo vsa gospodinjstva in drugi naslovniki občine Jesenice (http://www.gorenjskiglas.si/).

\section{Radio}

Radio Triglav Jesenice

Zavod $\mathrm{z}$ imenom Radio Jesenice je bil ustanovljen že leta 1964 in je bil na začetku slišan le na Jesenicah. Sredi sedemdesetih let se je razširil tudi med poslušalce tedanje radovljiške občine in se preimenoval v Radio Triglav. Širil pa se ni le po prostoru, ampak tudi po času. Leta 1972 se je začel med prvimi lokalnimi postajami v Sloveniji oglašati vsak dan (http://www.radiotriglav.si/).

\section{Televizija}

GTV - Gorenjska televizija dnevno pripravi od 5 do 6 ur programa. V programski ponudbi je poudarek na lokalnih in regionalnih dogodkih ter lepotah Gorenjske. V vsakodnevnih poročilih povzamejo dogodke dneva, razvojne načrte lokalnih skupnosti, uspehe na področju gospodarstva, kulture, športa, umetnosti in na ostalih področjih, ki so zanimiva in aktualna za gledalce Gorenjske (http:/www.gtv.si/).

\section{KAKO DRUŽINE NA JESENICAH KORISTIJO MOŽNOSTI ZA NEFORMALNO IZOBRAŽEVANJE, KI JIH PONUIA ŠIRŠE IN OŽJE OKOLIE?}

Raziskava o neformalnem izobraževanju $\mathrm{v}$ družinah je potekala spomladi 2006. Podatke smo zbrali s pomočjo anketnega vprašalnika, ki smo ga empirično obdelali. V obdelavo je bilo zajetih 69 družin učencev osmih razredov osnovne šole na Jesenicah.

Značilnosti anketiranih družin učencev osmih razredov so prikazane v spodnjih tabe-

\begin{tabular}{|l|c|}
\hline Število članov v družini & delež (v \%) \\
\hline dva člana & 9 \\
\hline trije člani & 22 \\
\hline Štirje člani & 43 \\
\hline več kot štirje člani & 26 \\
\hline
\end{tabular}

\begin{tabular}{|l|c|}
\hline Izobrazbena struktura staršev & $\begin{array}{c}\text { delež } \\
(\mathbf{v} \%)\end{array}$ \\
\hline nedokončana osnovna šola & 18 \\
\hline dokončana osnovna šola & 29 \\
\hline končana poklicna šola & 24 \\
\hline končana srednja šola & 22 \\
\hline končana višja, visoka šola, univerza & 4 \\
\hline specializacija, magisterij, doktorat & 3 \\
\hline
\end{tabular}




\begin{tabular}{|l|c|}
\hline Zaposlitveni status staršev & delež (v \%) \\
\hline brezposelni starši & 15 \\
\hline zaposleni starši & 85 \\
\hline
\end{tabular}

\begin{tabular}{|l|c|}
\hline Poklicni status staršev & delež (v \%) \\
\hline delavci & 59 \\
\hline usiužbenci & 30 \\
\hline samostojni podjetniki & 6 \\
\hline nižji vodilni & 3 \\
\hline vodstveni in vodiIni delavci & 2 \\
\hline
\end{tabular}

lah. Tabele nam prikazujejo število članov v anketiranih družinah, izobrazbeno strukturo, zaposlitveni in poklicni status staršev.

Podatki o izobrazbi staršev kažejo, da je izobrazbena struktura $v$ družinah slabain neugodna. Velik odstotek staršev ima nedokončano ali končano le osnovno ali poklicno šolo, ki ne dajeta osnove za vseživljenjsko izobraževanje, za izobraževanje $\mathrm{v}$ različnih okoliščinah, za različne življenjske in delovne vloge. $\mathrm{Na}$ sedanji stopnji družbenega in gospodarskega razvoja namreč šele končana štiriletna srednja šola zagotavlja ustrezno osnovo, ki posamezniku omogoča pridobivanje novega znanja, vrednot, spretnosti skozi vse življenje. Raziskave $\mathrm{v}$ tujini in pri nas kažejo, da so tisti odrasli, ki so najmanj izobraženi, najmanj motivirani za nadaljnje izobraževanje in izrabo možnosti, ki jih ponuja okolje, za pridobivanje novega znanja, spretnosti, razvijanje vrednot. Močna pozitivna zveza pa je tudi med ravnjo izobrazbe in zaposljivostjo. Na to kažejo tudi podatki o zaposlitvi staršev. Brez zaposlitve je kar 15 odstotkov staršev anketiranih družin.

Primarni vir, po katerem se zgledujejo otroci, so namreč starši in zato po njih oziroma skupaj z njimi usmerjajo svoj interes za izobraževanje. C̆e sta za starše znanje in izobrazba eni od osebnih kvalitet, se bo ta vrednota uvrstila tudi $v$ otrokov vrednostni sistem in

Manj izobraževani
odrasli so najmanj
motivirani za
izrabo možnosti,
ki jim jih ponuja
okolje.
mu trud pri doseganju te vrednote ne bo ovira. Starši, ki ne vrednotijo izobraževanja in izobraževanju ne namenijo dovolj pozornosti, prenašajo na otroke vse prej kot interes za izobraževanje in s tem nižajo nivo otrokovih izobraževalnih prizadevanj.

\section{KAKO DRUŽINE PREŽIVLJAJO PROSTI ČAS?}

Danes vse več ljudi razpolaga z novo dimenzijo časa. V mislih imamo prosti čas kot izvendelovni čas, za katerega se sami odločamo, kako in kje ga bomo preživeli. $\mathrm{V}$ prostem času stopamo $\mathrm{v}$ nove socialne skupine in $s$ tem tudi $v$ nova in drugačna interakcijska razmerja z drugimi. Kako preživimo prosti čas, ni nepomembno. Ljudem, ki niso pripravljeni, izobraženi za kaKakovostno
preživljanje pros-
tega časa je v
sodobni družbi vse
bolj povezano z
izobraževanjem za
osebnostni razvoj. kovostno preživljanje prostega časa, lahko

Od izobrazbe staršev je odvisna tudi kulturna raven družine, način preživljanja prostega časa. Starši, ki imajo neko formaIno izobrazbo, občutijo pomanjkanje znanja na določenih življenjskih področjih veliko prej kot starši, ki nimajo ustrezne izobrazbe. Izobraženi starši bodo znanje, ki je potrebno za vzgojo, črpali iz literature, sredstev javnega obveščanja, lahko se bodo tudi formalno izobraževali ..., starši, ki niso izobraženi, najpogosteje ne poznajo takih možnosti, saj ne čutijo potrebe po večjem znanju. Izobraženi starši bodo znali svojim otrokom posredovati kulturo $v$ najširšem pomenu besede in bodo s svojim odnosom do nje vplivali na otroke, da jih bodo posnemali. 
prosti čas predstavlja neko breme, ki ga težko prenašajo. Mnogi skušajo občutek osamljenosti, nekoristnosti, ki jih začne ogrožati v prostem času, »utopiti« $\mathrm{v}$ različnih odvisnostih. Kakovostno preživljanje prostega časa naj bi v sodobni družbi vključevalo vedno več izobraževanja za osebnostni razvoj.

Anketirani učenci najraje preživljajo prosti čas s sošolci, prijatelji (54 odstotkov anketiranih učencev). To bi si lahko razložili s tem, da prijatelji, sošolci postanejo v obdobju, v katerem se nahaja učenec osmega razreda, pomemben agens socializacije. S starši in starimi starši najraje preživlja svoj prosti čas 28 odstotkov učencev, tistih, ki najraje preživljajo prosti čas sami, je 16 odstotkov, 2 odstotka anketiranih učencev pa najraje preživlja prosti čas z drugimi sorodniki. Na vprašanje, kako s starši preživljajo prosti čas, so anketirani učenci v največjem odstotku odgovorili, da gledajo televizijo (25 odstotkov), delajo domače naloge in se učijo za šolo (18 odstotkov) ter da opravljajo gospodinjska opravila in delajo na vrtu (17 odstotkov). Odgovori nas spodbudijo $\mathrm{k}$ razmišljanju, ali navedene dejavnosti (domače naloge, gospodinjska opravila) niso bolj obveza in nuja kot pa sprostitev, interes. Ne smemo reči, da delo za šolo ni pomembno. Tudi to učenje ima pomen, posebno kadar se učimo $\mathrm{z}$ nekim globjim interesom, ne le zaradi ocen. Takrat tudi $v$ trenutkih družinske "sprostitve radi povemo drug drugemu, kaj smo se novega naučili, kakšna vprašanja so se nam ob tem zastavila. Že možnost »glasnega razmišljanja« je lahko spodbuda za nadaljnje izobraževanje. Toda preživljanje prostega časa je po drugi strani nekaj, kar pokaže interes in zanimanje posameznika, saj v prostem času posameznik dela tisto, kar želi, če pa dela tisto, kar mora, je to bolj nuja in obveza kot prosti čas. Glede na navedene odgovore anketiranih učencev ugotavljamo odsotnost aktivnosti, ki bi bile tesneje povezane s socialnim okoljem, sosesko, krajem. Televizija ljudi pogosto odvrne od aktivnega preživljanja prostega časa, čeprav je lahko po drugi strani pomemben vir informacij. Sami bi v ospredje kot pomembnejši vir novih doživetij postavili aktivnosti, ki omogočajo razmerja in socialne stike. Informacije namreč sprejemamo drugače, če si jih pridobimo v neposrednem stiku z drugimi ljudmi. Možnost navezave socialnih stikov predstavljajo prav gotovo izleti $v$ naravo (15 odstotkov učencev preživlja prosti čas $z$ izleti $v$ naravo) in obiski sorodnikov, znancev (navedlo jih je 11 odstotkov učencev). Socialne stike navezujemo tudi, ko beremo knjige, časopise in se o prebranem pogovarjamo z ljudmi (5 odstotkov učencev $\mathrm{v}$ prostem času bere knjige, časopise), se ukvarjamo s športom (4 odstotkov učencev se v prostem času športno udejstvuje), gremo v kino (3 odstotki učencev gredo v prostem času v kino), gledališče, obiščemo muzej, si ogledamo razstave (gledališče, razstave in muzej v prostem času obiščeta le 2 odstotka anketiranih učencev).

Glede na odgovore, kako učenci preživljajo prosti čas, je bilo zanimivo ugotoviti, kakšni so učenčevi dejanski interesi. Učenci so odgovorili, da jih najbolj zanima druženje $z$ ljudmi (22 odstotkov), šport in rekreacija (20 odstotkov), potovanja (17 odstotkov), narava (13 odstotkov). V manjših odstotkih se zanimajo za literaturo ( 9 odstotkov), tehniko (7 odstotkov), slikarstvo (6 odstotkov), gledališče (4 odstotke), politiko (2 odstotka). V ospredju so tako interesi po druženju, gibanju, sprostitvi ter odkrivanju novega.

\section{O ČEM SE POGOVARIAJO V DRLǏINAH?}

Človek se razvija in zori $v$ interakcijskih razmerjih $\mathrm{z}$ drugimi. Pomemben je tudi pogovor v družini. Živahen pretok sporočil med starši in otroki bogati procese interpersonalne komunikacije in s tem spodbuja osebnostni razvoj staršev in otrok oziroma 
vseh, ki so vključeni v medgeneracijski komunikacijski proces. Anketirani učenci so odgovorili, da se s starši največ pogovarjajo o problemih in težavah, povezanih s šolskim delom (za ta odgovor se je odločilo 78 odstotkov učencev), potem se pogovarjajo o pomembnih temah dneva (12 odstotkov), o problemih odraščanja (10 odstotkov). Iz omenjenih odgovorov bi lahko sklepali, da učence šolsko delo precej obremenjuje. Tudi odgovori o preživljanju prostega časa, kjer je precej učencev odgovorilo, da ga porabijo za šolsko delo, to domnevo podkrepijo. Uspehi in neuspehi pri izobraževanju prav gotovo vplivajo tudi na člane družine in na celotno družinsko ozračje. Kadar se katerikoli član družine čuti prisiljenega $\mathrm{k}$ učenju snovi, katere smisla ne vidi, takrat je takšno učenje emocionalno obremenjujoče za vso družino.

\section{KAM DRUŽINE POTUIEJO?}

Priložnost izobraževanja nudijo tudi potovanja. Iz običajnega potovanja lahko bodisi za razvedrilo ali zaradi zaslužka naredimo učno okolje, če si potovanje primerno strukturiramo tudi $z$ vidika učenja, če se zavestno potrudimo, da bi se na potovanju nečesa naučili (opazili, si zapomnili, razumeli, začutili, sprejeli). Na vprašanje Ali ste s starši kdaj potovali v tujino? je 86 odstotkov učencev odgovorilo pritrdilno, 14 odstotkov anketiranih učencev pa je odgovorili negativno. Ko so naštevali, kam so potovali, so močno prevladovale bližnje države Hrvaška, Avstrija, Italija, Madžarska, veliko število jih je potovalo tudi v Bosno, Srbijo, Črno Goro, v manjšini pa so bili ostali, ki so potovali v Grčijo, Španijo, Francijo, Veliko Britanijo. Navedeni odgovori ne presenečajo, saj Jesenice ležijo $v$ bližini pomembnih mejnih prehodov z Avstrijo in Italijo, poleg tega pa ima velik odstotek prebivalstva na Jesenicah korenine v državah bjvše Jugoslavije, zato tja veliko potujejo.

\section{KAKŠNO JE OBISKOVANJE KNJIŽNIC, BRANJE KNJIG, ČASOPISOV, REVIJ V DRUŽINAH?}

Anketirani učenci knjižnico obiščejo pogosto (83 odstotkov), redko 17 odstotkov učencev, odgovora nikoli pa ni obkrožil noben učenec. Tudi 65 odstotkov staršev knjižnico obišče pogosto, 35 odstotkov staršev pa redko. Omenjeni odgovori ne presenečajo, saj so knjižnice prepoznane kot nepogrešljive sodelavke posameznika in skupin $v$ procesu izobraževanja. Nepogrešljive so zlasti $v$ obdobju posameznikovega šolanja in tako so jih bolj ali manj »prisiljeni« obiskati tako učenci kot tudi njihovi starši. V obdobju, ko se otrok šola, starši obiščejo
Medgeneracijski komunikacijski proces bogati osebnostni razvoj tako staršev kot otrok. knjižnico in otroku pomagajo pri iskanju potrebnega gradiva, postavlja pa se vprašanje, koliko starši obiskujejo knjižnico tudi iz lastnega interesa in izobraževanja. Izkušnje so take, da knjižnice še vedno predvsem nagovarjajo osveščene prebivalce, prebivalce $\mathrm{z}$ opredeljenimi potrebami, ki zmorejo tudi sami poiskati učno gradivo, načine izobraževanja, manj kot je potrebno za današnjo stvarnost pa knjižnice nagovarjajo potencialne uporabnike. Da starši bolj kot iz svojega lastnega interesa obiskujejo knjižnico zaradi potrebe po pomoči šolajočemu otroku, sklepamo tudi iz odgovorov anketiranih učencev na vprašanje, kako pogosto vidijo starše pri branju. Kar 61 odstotkov anketiranih učencev je odgovorilo, da redko, 35 odstotkov pogosto, 4 odstotki učencev pa je odgovorilo, da staršev nikoli ne vidijo pri branju. Na vprašanje, kaj berejo starši, so v največjem odstotku obkrožili revije in časopise (52 odstotkov), sledijo knjige (39 odstotkov), strokovni tisk, učbeniki, priročniki (9 odstotkov).

$\mathrm{Na}$ otrokov razvoj, in sicer tako miselni in socialni kot tudi jezikovni, ter na razvoj neka- 


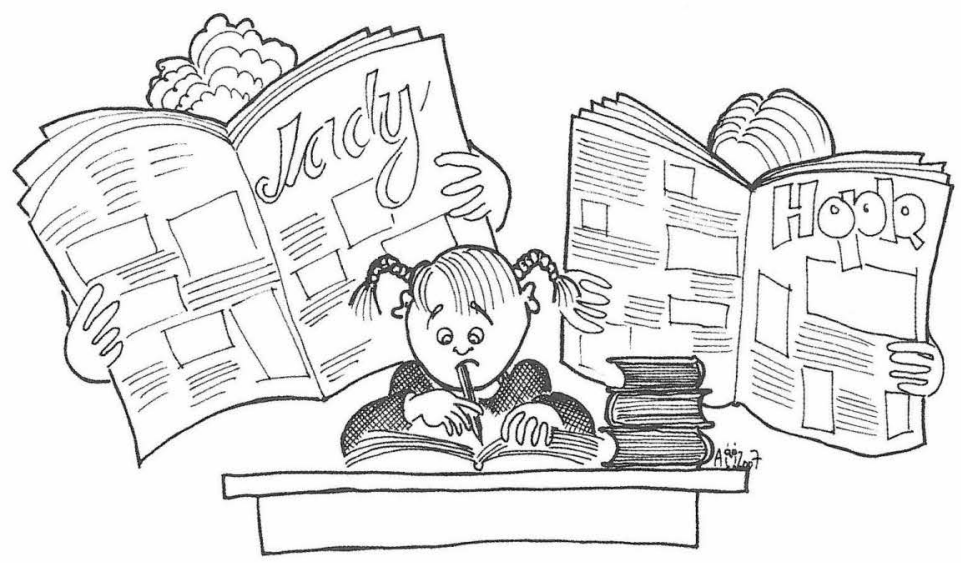

terih temeljnih akademskih spretnosti, kot sta branje in pisanje, ima prav gotovo pomemben vpliv tudi prisotnost knjig, časopisov in

Knjižnice $v$ večini primerov nagovarjajo osvescene prebivalce. revij v družini. Na vprašanje, ali imate doma knjige, je 78 odstotkov anketiranih družin odgovorilo $\mathrm{z}$ le nekaj, 18 odstotkov družin je obkrožilo odgovor, da imajo doma 100 in več knjig, 4 odstotki učencev pa je odgovorilo, da doma nimajo knjig. Da so doma naročeni na časopis, je pritrdilno odgovorilo 66 odstotkov družin, 39 odstotkov družin pa je odgovorilo, da doma niso naročeni na časopis. Največ družin je odgovorilo, da so naročeni na lokalni, regijski

Če so starši naročeni na časopis, revijo, je to dokaz, da se želijo informirati o dogajanjih doma in po svetu. Seveda imajo s tem enako možnost tudi otroci. Znano je tudi, da si ljudje, ki že imajo veliko informacij, teh želijo še več, tisti pa, ki jih imajo malo, si jih navadno ne želijo obogatiti. časopis (Gorenjski glas) (26 odstotkov), sledile so revije, kot so Hopla, Lady, Naša žena, Jana ... (23 odstotkov). Sedemnajst odstotkov jih je naročenih na dnevni časopis (Dnevnik, Slovenske novice, Delo ...), 13 odstotkov na tedenski časopis (Nedeljski dnevnik ...), 10 odstotkov na športni časopis in revije, 5 odstotkov na revije o avtomobilizmu, 3 odstotki na verski tisk, 2 odstotka na računalniške revije, 1 odstotek pa na revije o znanosti in tehniki. V ospredju je tako lokalni in regijski časopis, kar ne preseneča, saj je Gorenjski glas (s prilogo Jeseniške občinske novice JON) časopis Gorenjske regije in zato domač prebivalcem krajev, ki jim je namenjen.

\section{KAKO V DRUŽINAH POSLUŠAJO RADIO IN GLEDAJO TELEVIZIJO?}

Radio daje možnost za sprejem informacij v govorjeni ali glasbeni obliki. Največ anketiranih učencev je odgovorilo, da doma poslušajo Radio Belvi (56 odstotkov). To je gotovo ena izmed bolj priljubljenih postaj na Gorenjskem 
med mladimi. Program je glasbeno obarvan, popestren $z$ aktualnimi dogodki, pregledi domačega in tujega tiska, različnimi intervjuji, kino sporedi, informativnimi oddajami, glasbenimi željami. Program sooblikujejo tudi poslušalci. Poleg omenjene radijske postaje doma poslušajo tudi Radio Triglav Jesenice (22 odstotkov), Radio Slovenija (13 odstotkov) ter Radio Ognjišče (9 odstotkov). $\mathrm{Na}$ radiu najpogosteje poslušajo glasbene in zabavne oddaje (52 odstotkov), informativne oddaje in poročila posluša 26 odstotkov. Oddaje, $v$ katerih se gostje pogovarjajo o določeni temi, poslušajo v 13 odstotkih, oddaje, ki dajejo razne nasvete in izobražujejo, pa v 9 odstotkih. Navedeni odgovori ne presenečajo glede na odgovore o radijski postaji, ki jo doma učenci najbolj poslušajo (Radio Belvi). Prispevki s strokovnejšo tematiko in zanimivostmi, aktualnimi novicami, popestrenimi $\mathrm{z}$ javnim mnenjem in sodelovanjem poslušalcev, ter s posebej izbrano glasbo so bolj prisotni na ostalih radijskih postajah (Radio Slovenija, Radio Triglav Jesenice, Radio Ognjišče), ki jih učenci doma redkeje poslušajo.

Ob raznoliki ponudbi televizijskih programov nas je zanimalo, katere televizijske programe in oddaje najpogosteje spremljajo $\mathrm{v}$ družinah. Družine najpogosteje gledajo POP TV, programe Televizije Slovenije, A-kanal ter televizijski hrvaški program. Najpogosteje gledajo nadaljevanke in filme (37 odstotkov), poročila (19 odstotkov), glasbene, zabavne oddaje in kvize (15 odstotkov). Oddaje, v katerih se gostje pogovarjajo o določeni temi, spremlja 14 odstotkov družin, oddaje, ki dajejo razne nasvete in izobražujejo, spremlja 8 odstotkov, oddaje o življenje ljudi, naravi, tujih deželah pa spremlja 7 odstotkov družin.

\section{KAKO DRUŽINE UPORABLIAJO RAČUNALNIK?}

Računalnik je danes nepogrešljiv spremljevalec na poti izobraževanja, zlasti šolajočih se otrok. Ker predvidevamo, da večina učencev osmih razredov uporablja računalnik, nas je bolj zanimalo, kako pogosto uporabljajo računalnik njihovi starši. Odgovori so bili sledeči: redko ga uporablja 43 odstotkov staršev, nikoli 35 odstotkov staršev, pogosto pa 22 odstotkov staršev.

V dobi množičnih medijev so nam informacije na voljo $v$ časopisu, revijah, na radiu, televiziji, računalniku ... Svet postaja en sam splet informacij, komunikacij. Kulturne dobrine $v$ dobi radia, televizije in drugih množičnih medijev niso več v lasti bogatih, ampak so skupna last. Toda postavlja se vprašanje, ali jih ljudje znajo ceniti, sprejeti in razumeti njihovo sporočilo. Glede na dobljene rezultate ankete bi lahko rekli, da v družinah pot izobraževanja s pomočjo televizijskega in radijskega programa ali $s$ pomočjo računalnika še ni dovolj sprejeta kot možna pot izobraževanja. Na radijske in televizijske oddaje gledajo bolj kot na razvedrilo in zabavo ali pa jih sprejemajo kot splošno informacijo. Na ta način se $v$ ljudeh še vedno kopičijo samo gore informacij, ki nas »bombardirajo od vseh stani, vendar ljudi še naprej puščajo brez znanja.

\section{KAKO POGOSTO UČENCI OBIŠČEJO KINO, GLEDALIŠČE, OPERO, KONCERT, MUZEJ, RAZSTAVO, KNIIŽNICO, ŠPORTNO TEKMO?}

Odgovori na vprašanje, kako pogosto učenci obiščejo kino, gledališče, opero, koncert, muzej, razstavo, knjižnico, športno tekmo, nam kažejo, da učenci možnosti za neformalno izobraževanje, ki jih nudijo Jesenice kot okolje, v katerem živijo, ne izkoriščajo. Učenci in njihovi starši pri osebnem iskanju novega znanja ne znajo poiskati virov v svojem neposrednem okolju. 


\begin{tabular}{|l|c|c|c|}
\hline Kako pogosto učenci obiščejo? & $\begin{array}{c}\text { pogosto } \\
(\mathbf{v} \%)\end{array}$ & $\begin{array}{c}\text { redko } \\
(\mathbf{v} \%)\end{array}$ & $\begin{array}{c}\text { nikoli } \\
(\mathbf{v} \%)\end{array}$ \\
\hline kino & 39 & 52 & 9 \\
\hline gledališče & 13 & 65 & 22 \\
\hline opero, koncert & 4 & 18 & 78 \\
\hline muzej & 4 & 22 & 74 \\
\hline razstavo & 4 & 26 & 70 \\
\hline knjižnico & 83 & 17 & 0 \\
\hline športno tekmo & 39 & 44 & 17 \\
\hline
\end{tabular}

\section{SKLEPNE UGOTOVITVE}

V današnji družbi hitrih sprememb na vseh področjih človekovega življenja vzgoja in izobraževanje nista dokončan proces. Znanje moramo pridobivati vse življenje po načrtovani poti in naravnano $\mathrm{k}$ jasnim ciljem. Izobraževalni proces se zaradi tega $v$ družbi hitrih sprememb seli iz formalnih institucij $\vee$ človekov intimni svet in se odziva
Možnosti za izobraževanje otrok so prepogosto odvisne tudi od socialnoekonomskega položaja družine. na najbolj osebne vzgibe. Prav tako dobiva na pomenu neformalno izobraževanje, ki ubira bolj spontane poti, vraščene $v$ življenje, potrebe in druge spremembe.

Družinskookoljejepomemben dejavnik, ki otroke spremlja in usmerja na njihovi poti učenja in izobraževanja ter vpliva na njihovo učno uspešnost. Os- nove znanja in izkušenj namreč otroci dobijo $\mathrm{v}$ primarni družini in znanje dopolnjujejo $\mathrm{v}$ interakciji s šolskim okoljem.

Poleg ožjega okolja (družine), v kateri otrok odrašča, vpliva na razvoj otroka tudi širše okolje s svojo kulturno, socialno in materialno razvitostjo. Pri odkrivanju lokalnih središč neformalnega izobraževanja na Jesenicah smo ugotovili, da je možnosti neformalnega izobraževanja in aktivnega preživljanja prostega časa na Jesenicah kar nekaj. Kljub možnostim, ki jih nudijo Jesenice kot okolje, v katerem družine živijo, smo $\mathrm{v}$ raziskavi ugotovili, da družine teh možnosti pri osebnem iskanju novega znanja ne znajo poiskati. Na slabo prisotnost neformalnega izobraževanja $v$ družinah učencev osmih razredov prav gotovo vpliva nizka izobrazba staršev, saj je znano, da so bolj izobraženi starši dejavnejši (berejo knjige, časopise, obiskujejo knjižnico), bolj preskrbljeni z bralnim gradivom in bolj spremljajo javne, kulturne, športne ter druge prireditve, medtem ko je pri manj izobraženih starših večji delež nedejavnih, spremljanje različnih prireditev je redko, večkrat pridobivajo informacije $\mathrm{z}$ vidika pismenosti le preko radia in televizije.

Majhno prisotnost neformalnega izobraževanja v družinah bi lahko povezali tudi $z$ zaposlitvijo in poklicem staršev (povezan je z izobrazbo). Glede na omenjeno, bi lahko predvidevala tudi, da na prisotnost neformalnega izobraževanja v družini vpliva tudi ma-

Družinski člani prenašajo na otroke določen nivo pismenosti in kulturne usposobljenosti, ki vpliva na njihovo učno uspešnost. $V$ kolikšni meri ga družinski člani prenesejo na otroke, pa je odvisno od izobrazbe in zaposlitvene dejavnosti staršev, prav tako pa tudi od njihove usmerjenosti v razvijanje družinskih aktivnosti, s katerimi lahko otroke opremijo $\mathrm{z}$ bralnimi, pisnimi in drugimi spretnostmi in znanjem. Starši in drugi družinski člani, ki izobraževanju pripisujejo velik pomen, lahko otrokom neposredno pomagajo pri učenju, razvijanju delovnih in učnih navad, prav tako lahko skupaj obiščejo gledališče, predstave in druge kulturne institucije, s čimer jim omogočajo izkustveno učenje, hkrati pa raznolike načine pridobivanja znanja. Starši in drugi družinski člani otroke s svojimi dejanji spodbujajo k izobraževanju in jim pokažejo, da je izobraževanje smiselno in kakovostno ne glede na starost. 
terialni status družine, saj zaposlitveni status $\mathrm{v}$ veliki meri določa strukturo virov dohodka, skupaj z izobrazbeno ravnjo pa tudi višino dohodka. Iz navedenega izhaja, da višja kot je izobrazba staršev in $s$ tem tudi večji prihodki, večja je verjetnost, da bo družina lahko kvalitetneje preživljala svoj prosti čas $v$ primerjavi $z$ družino $z$ neugodnim materialnim položajem, ki bo osredotočena bolj na zagotavljanje življenjskih sredstev. Boljši socialnoekonomski položaj družine torej omogoča večje možnosti za izobraževanje otrok, dostop do informacij in izrabo virov, ki jih ponujata ožje in širše okolje, neugoden socialnoekonomski status družine pa daje manjše možnosti za vključevanje otrok v različne oblike učenja in izobraževanja.

Prisotnost neformalnega izobraževanja v družini vpliva na učno uspešnost učencev. Kako bo otrok razvijal svoj odnos do učenja in izobraževanja, je odvisno tudi od tega, kako vrednotijo učenje in izobraževanje njegovi straši. Otroci se mnogokrat zgledujejo po starših. V primeru, ko starši pridejo na svoj način do znanja (npr. obiščejo knjižnico ...) in če so tovrstna dejanja otrokom všeč, so možnosti večje, da bodo tako ravnali tudi otroci in takšna dejanja razvijali naprej. Če pa v družini učenje in izobraževanje nimata nobene vrednosti in veljave, je bolj verjetno, da bo v skladu s tem tudi otrok razvijal svoje stališče do učenja in izobraževanja.

\section{LITERATURA}

Bergant, M. (1962). Okolje in razvoj slovenskih otrok. Ljubljana: DZS.

Husen, T. (1974). The Learning Society. Richard Clay Ltd.

Jełenc, Z. (1991). Terminologija izobraževanja odraslih. Ljubljana: Pedagoški inštitut.

Jelenc, Z. (1992). Neformalno izobraževanje odraslih v organizacijah (doktorska disertacija). Ljubljana.

Jelenc, Z. (1998). Vseživljenjsko izobraževanje in vseživljenjsko učenje. Ljubljana: Andragoški center Slovenije.

Krajnc, A. (1996). Kakšno znanje potrebuje sodobni človek. Andragoška spoznanja, št. 3, str. 5-10.

Krajnc, A. (1997). Vseživljenjsko izobraževanje ali vseživljenjsko učenje. Andragoskka spoznanja, št. 3/4, str. 3 .

Krajnc, A. (2000). Spontano individualno izobraževanje. Andragoška spoznanja, št. 3, str. 48-51.

Krajnc, A. (2002). Uěna okolja. Andragoška spoznanja, st. . , str. 3-5.

Ličen, N. (1998). Prosti cas v družini. Otrok in družina, st. 7-8, str. 34-35.

Lengrand, P. (1970). An Introduction to Lifelong Education. Paris: Unesco.

Tough, A. (1971). The Adults Learning Projects. Torino: The Ontario Institute for Stu-dies in education.

Toffer, A. (1992). Future Shock. New York: Bantam Books.

Walter, G. A, Marks, S. E. (1981). Experiential Learning and Change. Theory Design and Practice. New York.

Elektronski viri:

http://www.jesenice.sif

http:/www.gornjesavskimuzej.si/

http://www.knjiznica-jesenice.org/novice.php

http://www.jesenice-tourism.net/

http:/www.gorenjskiglas.si/.

http:/www.radiotriglav.si/

http://www.gtv.si/

http:/www.gledalisce-tc.si 